\title{
MANAJEMEN EMOSI PADA ANAK USIA DINI
}

\author{
Nurjanah, Ira Miranti, Nina Dwiastuty \\ Program Studi Pendidikan Bahasa Inggris \\ Fakultas Bahasa dan Seni, Universitas Indraprasta PGRI \\ Jl. Nangka no.58c, Tanjung Barat, Jagakarsa, Indonesia
}

\begin{abstract}
Abstrak
Saat melakukan manajemen emosi pada anak usia dini, orangtua harus dalam kondisi tenang dan terkendali. Bukannya meneriaki balik si anak, menceramahinya panjang-lebar, atau bahkan menekannya dengan tujuan ia sadar terhadap kesalahannya. Semua itu akan sia-sia ketika kondisi si anak, juga kita, masih panas. Jadi, pertama-tama, tenangkan diri sendiri dulu, baru setelah itu tenangkan si anak. Kunci keberhasilan anak mengendalikan diri dimulai dari orangtua yang mampu berbuat demikian lebih dulu. Hal ini tidak akan tercapai apabila ayah atau ibunya masih mudah marah dalam menyelesaikan masalah. Setelah tenang, berikut hal-hal yang hendaknya orangtua lakukan saat si anak sedang emosi yaitu mengetahui penyebabnya, mengalihkan perhatiannya, bersikap tenang, memberikan perhatian dan pelukan, dan membiarkan anak tenang terlebih dahulu sebelum diajak berdiskusi.
\end{abstract}

Kata kunci: manajemen emosi, anak usia dini,

\begin{abstract}
When managing early childhoods' emotions, parents shall be in completely calm and controlled state of mind. They shall not yell at the children, give them lengthy preach, or press them to make them aware of their mistakes. All of those efforts would be in vain because parents themselves are still emotional. Therefore, parents must calm themselves down first. When the parents are in complete control of their emotions, they could start to calm their children. The key to the success of calming children and making them aware of their mistakes is parents' competence to manage their own emotions and problems. Such success won't be achieved if parents resort to anger in solving problems. When emotions have subsided, parents could do the followings; learn the source of the problems, divert the children's attention, stay calm, give the children attention, physical contacts such as a hug, and time to calm themselves down, and finally - when everybody gains peace of mind involve the children in a discussion.
\end{abstract}

Key words : Emotional management, early childhood

Correspondence author: Nurjanah, nurjanah3434@yahoo.com, Jakarta, Indonesia

(c) (i) (8)

\section{PENDAHULUAN}

Di zaman milineal ini, kebutuhan hidup cepat terpenuhi dan aktivitas sehariharipun semakin mudah dengan adanya teknologi yang semakin canggih. Sebut saja gadget salah satunya adalah handphone). Bentuk barang ini kecil tapi berdampak 
banyak pada kehidupan manusia. Sekarang handphone bukan merupakan barang mewah lagi. Masing-masing anggota keluarga memilikinya. Handphone agaikan pisau bermata dua, bias menjadi baik atau buruk. Jika kita ingin pergi ke suatu tempat maka kita hanya menekan tombol/ memilih menunya saja. Begitu juga jika kita merasa lapar hanya pilih menu saja. Untuk para pebisnis atau pengusaha, handphone ini sangat menguntungkan bagi mereka karena dapat mempromosikan produk mereka. Jika kita sibuk tidak bias pergi ke mall, maka kita bias berbelanja online. Bayar listrik, transfer uang sekarang juga bias melalui handphone. Itulah kegunaan handphone jika kita memanfaatkannya secara benar. Seperti pada motto Go-Jek" hidup tanpa batas"

Handphone menjadi tidak baik jika penggunaannya disalahgunakan. Fenomena sekarang ini para kaum ibu yang memiliki anak kecil (balita), mereka biasanya memberikan handphone ke anak-anak mereka supaya anak mereka tidak rewel. Anak kecil zaman sekarang sudah bias mengoperasikan handphone, mereka hanya harus menekan tombol menu saja tanpa mengetahui bacaan instruksi tersebut. Hal ini sebenarnya bukanlah suatu yang luar biasa, mereka melihat apa yang ibunya kerjakan. Karakter seorang anak adalah meniru dan mencontoh apa yang orang lain lakukan. Begitu juga anak usia Sekolah Dasar dari kelas 1 sampai kelas 6, kebanyakan dari mereka sudah memiliki handphone. Mereka berdalih ingin berkomunikasi kepada teman- temannya atau ingin mencari pengetahuan baru dengan melakukan googling. Tetapi kenyataaannya, handphone digunakan untuk bermain game saja. Dalam hal ini seharusnya orangtua mengontrol aplikasi hand phone yang dimilliki anak dan mengontrol juga apa yang sedang dilakukan anaknya. Selain handphone yang dimiliki oleh setiap keluarga, televise juga lebih dari satu buah di setiap rumah ada. Orang tua membelikan televise untuk anaknya supaya dapat menonton film atau acara lainnya sendiri. Orangtua sibuk dengan urusannya masing-masing. Mereka membiarkan anaknya menonton acara televise sendiri tanpa mendampinginya. Mereka jarang mendampingi anaknya belajar. Mereka lebih senang mengirimkan anaknya belajar membaca ke tempat kursus atau bimbingan belajar calistung (membaca, menulis dan berhitung).

Melihat fenomena yang terjadi sekarang ini, banyak orangtua yang seakan-akan lupa akan peranannya sebagai orangtua. Kewajiban orangtua adalah mendidik, mengajarkan, dan mengawasi anaknya secara ekstra. Orangtua harus memberikan contoh/ mempraktekkan sesuatu kepada anaknya, dengan memberikan contoh itulah anak secara tidak langsung dididik kecerdasan emosi dan kecerdasan intelegensinya. Contoh: mengajarkan anak cara makan yang benar, mengajarkan anak duduk yang benar, mengajarkan anak tidur yang benar, mengajarkan anak menaruh sepatu pada tempatnya, mengajarkan anak menaruh buku pada tempatnya, mendidik anak untuk menggunakan gadget/handphone pada waktunya. Orangtua mengajarkan anaknya dimulai dari hal-hal yang kecil yang ada disekitar lingkungan keluarga dan kegiatan yang mereka sering lakukan. Pada contoh di atas, kecerdasan emosi yang diajarkan anak adalah anak dapat mengendalikan diri tidak melempar sepatu atau buku sembarangan, mereka bias merasakan pada hati mereka sendiri hal-hal yang baik dan tidak. Kemudian berkembanglah kecerdasan intelegensinya yaitu mereka dapat menempatkan sesuatu pada tempatnya. Orangtua mengajarkan anaknya hal-hal seperti contoh di atas adalah dalam rangka membuat pola pikir/ kerangka berpikir anak. Mereka bias memilih dan memilah sesuatu yang baik dan tidak maka terbentuklah pola pikir/ kerangka berpikir. Jadi orangtuanyalah yang membentuk kerangka berpikir pada anaknya sendiri. Jika kerangka berpikir anak sudah bagus, anak akan merasa senang, belajar pun akan terasa 
mudah. Tetapi jika anak kerangka berpikirnya belum terbentuk maka anak akan malas belajar, diajari sesuatu sulit dan ia juga akan sulit menghapal. Jika seorang anak sukses dalam hidupnya, orangtuanyalah yang berhasil membentuk kerangka berpikir anak. Dengan demikian orangtua wajib mendidik anaknya dari usia dini baik kecerdasan emosi maupun intelegensinya, bukan hanya sekedar pintar tapi kepintarannya terarah. Sebagaimana sabda Rosulullah SAW "Kullu mauludin yul adual al fitroh". Artinya "Setiap anak dilahirkan dalam keadaan suci". Anak, bersih dari dosa, bersih dari pikiran-pikiran tidak baik, bersih dari keinginan/ ambisi yang tinggi. Maka dari itulah tugas orangtua harus mendidik anaknya, tidak hanya diajarkan kecerdasan kognitifnya saja namun juga harus diajarkan kecerdasan emosinya juga. Supaya kecerdasan intelegensinya terarah dan kecerdasan emosinya juga tertata. Banyak di sekitar kita sekarang orang cerdas tapi akhlaknya tidak terpuji.

Merujuk pada paparan di atas betapa pentingnya kecerdasan emosi diajarkan orangtua kepada anaknya dari sedini mungkin. Sebagaimana yang dikatakan oleh Agustian (2009:9) kecerdasanemosi (EQ) adalah kemampua nuntuk merasa. Kunci kecerdasan emosi adalah kejujuran pada suara hati. Suara hati itulah yang harusnya dijadikan pusat prinsip yang mampu memberi rasa aman, pedoman, kekuatan serta kebijaksanaan. Hal senada diungkapkan oleh Mubayidh (2006:19), EQ adalah empati (emphaty). Empati didefinisikan sebagai" kemampuan seseorang untuk merasakan apa yang dirasakan oleh orang lain”. Contoh, faktor yang paling mendorong pelanggan untuk membeli barang adalah kemampuan penjual untuk mengenali perasaan pelanggan, dan kemudian merespon perasaan ini dengan tepat.

Mubayyidh (2009:22) menggambarkan rincian tentang EQ, yaitu 1) EQ untuk diri sendiri, meliputi: mengenali diris sendiri, menghormati diri sendiri, menyikapi emosi sendiri, dan melejitkan potensi diri. 2) EQ untuk orang lain, meliputi empati pada orang lain dan interaksi dengan orang lain.

\section{METODE PELAKSANAAN}

Alasan utama dipilihnya mitra TK RA Nurussaadah karena peserta didik di sekolah tersebut tingkat emosinya masih tinggi, mereka masih sering berselisih, mereka masih egois terhadaptemannya. Peserta didik ada yang aktif dan tidak. Sebagian dari peserta didik masih sulit untuk diatur. Oleh karena itu permasalahan mitra yang akan kami coba tangani adalah: 1) Memberikan pemahaman tentang manajemen emosi pada anak usia dini dan usaha yang dapat dilakukan guru dan orang tua dalam manajemen emosi pada anak usia dini. 2) Memberikan praktik kepada guru dan orang tua dalam menangani anak usia dini yang sedang berada dalam kondisi emosi sehingga control emosi mereka dapat dikendalikan.

\section{HASIL DAN PEMBAHASAN}

Hasil kegiatan ini adalah masyarakat sangat antusias ketika kami memberikan Sosialisasi Manajemen Emosi pada Anak Usia Dini kepada para guru dan orang tua murid di TK RA Nurussaadah J1. H. Saidi No.46 RT 007/ 05 Tanjung Barat Jagakarsa JakSel, manajemen emosi pada anak usia dini masih rendah. Setelah kami memberikan sosialisasi kepada para para guru dan orang tua murid di TK RA Nurussaadah bahwa kita harus meningkatkan manajemen emosi pada anak usia dini perlu ditingkatkan. 
Pendekatan yang dilakukan dalam kegiatan pengabdian masyarakat ini adalah dengan melakukan: Presentasi tentang manajemen emosi pada anak usia dini di TK RA Nurussaadah, Tanya jawab tentang manajemen emosi pada anak usia dini di TK RA Nurussaadah, dan Praktik manajemen emosi pada anak usia dini di TK RA Nurussaadah. Pendekatan ini dilakukan agar para guru dan orang tua murid mendapatkan pengetahuan tentang bagaimana mengendalikan emosi pada anak usia dini, bagaimana orangtua mengajarkan anaknya untuk membentuk pola pikir/ kerangka berpikir yang dimiliki anak, sehingga sang anak dapat menyeimbangkan antara kecerdasan emosional dan kecerdasan intelegensinya secara bersamaan. Para orangtua dapat mengaplikasikan pengetahuan yang mereka dapat di lingkungan keluarganya.

Sejak lahir anak-anak sudah memiliki berbagai emosi (seperti marah, senang, cemas, sedih, dan sebagainya) yang akan terus berkembang seiring pertumbuhannya. Sebagai orangtua, Anda wajib tahu bagaimana cara mengendalikan emosi anak agar ia memiliki kecerdasan emosional yang baik.

Selama masa pertumbuhan anak, emosi alaminya akan bercampur dengan apa yang ia lihat dari lingkungan sekitarnya. Oleh karena itu, gaya parenting yang tepat akan sangat penting untuk mengendalikan emosi anak. Sebelum orang tua mengajarkan bagaimana cara mengendalikan emosi anak, sebaiknya ajari anak terlebih dahulu untuk mengenali dan mengidentikasi perasaannya. Misalnya, sedih, marah, kecewa, malu, senang, benci, dan sebagainya.

Berdasarkan riset, mengidentifikasi emosi adalah tahap awal dalam mengendalikan emosi anak. Jangan sampai anak tak mengerti perasaannya sendiri sehingga ia menjadi gagal mengontrolnya di kemudian hari.Di usia $1-5$ tahunini, rasa takut adalah emosi yang paling sulit dimengerti dan diatas ioleh balita. Pada usia ini juga, orangtua mulai mengakrabkan anak dengan emosinya sendiri. Misalnya saat ia menangis, orang tua perlu bertanya apa yang ia rasakan. Saat ia senang, orang tua juga mulai bias mengajaknya berinteraksi tentang apa yang membuatnya senang. Misalnya Bunda bertanya, "Kok dedek keliatan sedih? Kenapa? Sini coba cerita sama Bunda." Atau bias juga, "Dedek seneng sekali? Coba certain ke Ayah" Di usia balita, mereka sudah mulai bias berkompromi dengan emosinya sendiri. Namun orang tua harus mulai berhati-hati karena balita akan meniru respon orangtuanya dalam segala situasi. Jadi, lebih berhati-hati dalam bersikap. Karena Anda adalah idola pertama anak, maka Andalah yang akan ditiru olehnya.

Penelitian menunjukkan bahwa semakin tenang kita berbicara, semakin tenang juga perasaan kita, dan orang lain akan meresponnya dengan tenang pula. Sebaliknya, bola kita banyak menggunakan kata-kata kasar, akan membuat kita dan juga orang yang mendengarkan merasa semakin kesal, dan situasi pun akan ikut memanas. Kita memiliki kekuatan untuk menenangkan atau semakin membuat marah baik untuk diri kita maupun lawan bicara kita dengan mengendalikan nada bicara dan juga pemilihan kata yang digunakan. (Ingat, sebagai orangtua Anda adalah panutan bagi anak.).

Beberapa cara yang dapat kita lakukan untuk membantu anak mengendalikan emosi dan meredam amarah anak-anak yang masih berusia dini adalah sebagai berikut:

\section{Mengetahui penyebabnya}

Pastikan Anda mengetahui terlebih dulu penyebabnya. Berbagai penyebab anak marah dan meluapkan emosinya karena lingkungan kurang nyaman, keinginanny atidak terpenuhi, lapar, bosan, dan mengantuk. Hal ini akan membantu Anda untuk mencegah ledakan emosi yang dialami anak di kemudian hari. Apabila anak sedang mengalami kekecewaan, berikan empati terlebih dulu kepadanya, baru kemudian menasihatinya. 


\section{Mengalihkan perhatiannya}

Dengan mengalihkan perhatian, anak akan melupakan kekecewaan dan kemarahan yang dirasakannya. Pengalihan perhatian ini, misalnya dengan mengajaknya melakukan aktivitas yang menyenangkan seperti menggambar, bernyanyi, berolahraga, bersepeda, dan bermain mainan favoritnya.

\section{Bersikap tenang}

Anak yang tiba-tiba marah memang bias menyulut emosi Anda. Namun, berusahalah untuk bersikap tenang dan santai menghadapi si Kecil. Sikap tenang akan membuat Anda lebih mudah mencari solusi untuk meredakan amarah anak. Jangan sampai Ayah bunda tersulut emosi yang sama, jika kejadian tersebut terjadi di tempat umum, bawalah anak ke tempat sepi dan hindari untuk memarahinya.

\section{Memberi perhatian dan pelukan}

Bagi beberapa anak, perhatian dan pelukan Ibu dapat membuatnya merasa nyaman dan aman. Ledakan emosinya sedikit demi sedikit bias berkurang saat Anda memeluknya dan memberikan perhatian positif kepadanya. Hal ini akan membuatnya merasa senang dan disayangi.

\section{Biarkan anak tenang dulu untuk diajak berdiskusi}

Lebih baik Anda menunggu sampai anak merasa tenang baru kemudian mengajaknya berbicara mengenai masalahnya. Ketika anak sudahtenang, akan lebih mudah diajak berdiskusi untuk mengatasi masalahnya.

Setelah kami memberikan Sosialisasi Manajemen Emosi pada Anak Usia Dini kepada para guru dan orang tua murid di TK RA Nurussaadah Jl. H. Saidi No.46 RT 007/ 05 Tanjung Barat Jagakarsa JakSel para guru dan orang tua murid sangat antusias dan akan mengupayakan untuk memulai melakukan manajemen emosi untuk anak-anak mereka di rumah.

\section{SIMPULAN}

Saat melakukan manajemen emosi pada anak usia dini, orangtua harus dalam kondisi tenang dan terkendali. Bukannya meneriaki balik si anak, menceramahinya panjang-lebar, atau bahkan menekannya dengan tujuan ia sadar terhadap kesalahannya. Semua itu akan sia-sia ketika kondisi si anak, juga kita, masih panas. Jadi, pertamatama, tenangkan diri sendiri dulu, baru setelah itu tenangkan si anak. Kunci keberhasilan anak mengendalikan diri dimulai dari orangtua yang mampu berbuat demikian lebih dulu. Hal ini tidak akan tercapai apabila ayah atau ibunya masih mudah marah dalam menyelesaikan masalah.

Setelah tenang, berikut hal-hal yang hendaknya orangtua lakukan saat si anak sedang emosi yaitu mengetahui penyebabnya, mengalihkan perhatiannya, bersikap tenang, memberikan perhatian dan pelukan, dan membiarkan anak tenang terlebih dahulu sebelum diajak berdiskusi. Karena orang tua adalah idola pertama anak, maka kitalah yang akan ditiru olehnya. Semakin tenang kita berbicara, semakin tenang juga perasaan kita, dan orang lain akan meresponnya dengan tenang pula. Sebaliknya, apabila kita banyak menggunakan kata-kata kasar, akan membuat kita dan juga orang yang mendengarkan merasa semakin kesal, dan situasi pun akan ikut memanas. Kita memiliki kekuatan untuk menenangkan atau semakin membuat marah baik untuk diri 
kita maupun lawan bicara kita dengan mengendalikan nada bicara dan juga pemilihan kata yang digunakan. (Ingat, sebagai orangtua kita adalah panutan bagi anak.).

\section{DAFTAR PUSTAKA}

Agustian, A. G. (2009). ESQ EMOTIONAL Spiritual Quotient. Jakarta: Arga Publishing.

Mubayyidh, M. (2006). Kecerdasandan Kesehatan Emosional Anak, Jakarta: Pustaka Al-Kautsar. 